J. Dairy Sci. 98:9061-9061

http://dx.doi.org/10.3168/jds.2015-98-12-9061

(C) American Dairy Science Association ${ }^{\circledR}, 2015$.

\title{
Corrigendum to "Differential expression of living mammary epithelial cell subpopulations in milk during lactation in dairy cows" (J. Dairy Sci. 98:6897-6904)
}

M. Baratta, M. G. Volpe, D. Nucera, G. Gabai, N. Guzzo, M. Fustini, and E. Martignani

Author M. Fustini's name was shown incorrectly in the published article (M. Faustini). The authors regret the error.

\section{REFERENCES}

Baratta, M., M. G. Volpe, D. Nucera, G. Gabai, N. Guzzo, M. Fustini, and E. Martignani. 2015. Differential expression of living mammary epithelial cell subpopulations in milk during lactation in dairy cows. J. Dairy Sci. 98(10):6897-6904. http://dx.doi.org/10.3168/jds.2015-9369. 